I apologise for the imperfection of details in the plea, but it seems to me to be a great opportunity for this society to initiate or to assist in promoting legislation for the removal of this social stain, or if unable to give the time for formulating a distinct plan of attack at any rate to give its support to other associations which are working in the same direction. So long as people can have access to unlimited amounts of intoxicants we cannot hope for universal moderation, nor can legislation stop drunkenness, which is often as much a symptom of disease as delirium may be of a fever. We can teach people the necessity for moderation (and probably we have in this been to some extent successful), but alcohol is always a dangerous instrument, and we cannot be surprised if some who do not know how to use it as a servant find that it becomes a tyrannous master. Drunkenness is not the end for which alcohol is taken, but the social system which permits the insidious ensnarement of control, welling up finally to a paralysing incompetence for economic duties, should also provide the means for escape from the net, if even by temporary restraint of another kind, and it should resolve that the possession of such a power is not a futile asset.

Harley-street, $w$.

\section{A CASE OF ACID INTOXICATION FOLLOW ING THE ADMINISTRATION OF CHLOROFORM.}

By HENRY THORP, M.B., Ch.B., M.Sc. VioT.,

ENIOR HOUSE SURGEON TO THE STAFFORDSHIRE GENERAT INFIRMARY, STAFFORD.

CASES of "delayed chloroform poisoning" are probably of sufficient rarity to warrant the publication of the following brief notes.

The patient, a bright, well-developed, apparently healthy boy, aged three years and ten months, was admitted on Jan. 28th, 1908, suffering from phimosis. He was recently recovered from an attack of chicken-pox but showed no symptoms of renal complications. Circumcision was performed at 11 A.M. on the 29th. Two drachms of chloroform were given, the administration lasting about seven minutes. The anæsthetic was well taken. He slept after the anæsthetic but was fally roused during the course of the afternoon. $\mathrm{He}$ vomited at $530 \mathrm{P}$ M. after sips of hot water and several times after that until 830 P.M., the vomit so far being quite clear. At that time he was fully conscious and laughing and talking. He slept from 8.30 P.M. until 1 A.M. on the 30 th, when attention was attracted by noisy respiration, with a marked rattle in the throat. The pulse now was rapid, of small volume, and feeble. The child could not be roused. The lungs were examined and found to be full of moist râles. He was given a medicine four-hourly containing liquor ammonii acetatis, ten minims ; spiritus æetheris nitrosi, four minims ; and vinum ipecacuanhæ, two minims. He continued to vomit on several occasions during the night, the vomit being of a dark green colour (bile) and smelling strongly of chloroform. He passed urine and the bowels were moved three times unconscionsly during the night. His temperature did not rise above $99^{\circ} \mathrm{F}$. during the night, but his pulse-rate was 120 and his respirations were 36 per minute. At 7.30 A.M. he was still unconscious, the pulse was weaker, but the respirations were less laboured. His condition improved slightly until $9 \mathrm{~A} . \mathrm{M}$., then he was pulseless, still vomiting occasionally. The lungs were again examined and found to be clear except for a few râles at the bases of the left lung. The abdomen was relazed. All the reflexes were normal (extensor plantar reflex on both sides). The pnpils were rather small but reacted normally to light. The tongue was moist but covered with a thick white fur. He still had incontinence of urine. At 10 A.M. the temperature had risen to $103^{\circ}$, the pulse could not be felt at the wrist, but the heart rate was over 200 per minute. He again vomited bile-stained fluid. He was ordered 30 minims of brandy by the mouth half-hourly and one-sixtieth of a grain of strychnine sulphate and five minims of ether hypodermically four-hourly. The administration of oxygen given warmed and in a continuous slow stream was commenced and continued until the end came. At 11.45 A $\mathbf{M}$. a slight general twitching was reported to have occurred twice. The palse had improved again slightly, the pulse-rate now being 144 ; the temperature was $103^{\circ}$ still. At 12.50 P.M. he vomited again. At 2 P.M, the temperature being still $103^{\circ}$, he was tepid sponged, which reduced it to $101^{\circ}$; the pulserate was then 144 . At 4 P.M. the smell of acetone was distinguishable in the breath and a catheter specimen of urine was obtained and sent to the Clinical Research Association for examination. The breathing remained fairly good until about 5 P.M. and then numerous râles were beard all over the chest. From 7.15 P.M. he screamed frequently for half an hour. At 7.30 P.M. the eyes were fixed, the pupils were equal, somewhat small, insensitive to light, the corneal reflex had gone, and the conjunctiva was dry. Up to this time he had remained in a state of apathy, from which it was impossible to arouse him, but he swallowed small drinks; he now became quite comatose. At 830 P.M. the pulse was again weaker and only palpable occasionally. The temperature was $102^{\circ}$. At 9 P M., the skin being very dry, a hot pack was given but it produced no action of the skin. Half-pint saline enemata containing 30 grains of bicarbonate of sodinm were given four-hourly from $10 \mathrm{~A} \mathrm{M}$. At $6 \mathrm{P} . \mathrm{M}$. and at $830 \mathrm{P}$ M. nutrient enemata of egg, starch, peptonised milk, and saline solution were given, the first only being retained. Champagne, in half-ounce doses, was given half-hourly from $9 \mathrm{P} . \mathrm{M}$. The child died at $11.45 \mathrm{P}$ M. on Jan. 30th, $36 \frac{3}{4}$ hours after the operation and about 23 hours after the onset of symptoms.

The report from the Clinical Research Association on the urine read as follows: "The amount of urea in this specimen is 1.90 per cent., or $8 \cdot 31$ grains per ounce. The urine gives a distinct reaction for acetone but the reaction for diacetic acid is extremely doubtful." A report on a specimen of blood sent at the same time read: "This specimen gave no reaction for acetone but the amount was too small for decisive results." Unfortunately I was unable to obtain a post-mortem examination in this case.

The chief interest of the case lies in the rapidly fatal termination following the brief exhibition of chloroform for a minor and frequently occurring operation and the fact that no antiseptics were used such as might have contributed to the cause of death. My best thanks are due to Mr. F. Herbert Marson for permission to publish the notes on this case.

Stafford.

\section{THREE CASES OF DELAYED CHLORO- FORM POISONING.}

By E. D. TELFORD, M.A., B.C. CANTAB., F.R.C.S. ENG., SURGEON TO THE MAXOHESTER FOSPITAL FOR SICK CHILDREN, PENDLEBURT.

THE three following cases appear to be definite examples of poisoning by the delayed action of chloroform. Cases 1 and 2 died within 48 hours of the administration of chloroform, whilst Case 3 recovered after a severe illness marked by those symptoms which are now regarded as typical of the condition.

CASE 1.-A boy, aged two and a half years, was admitted to Liebert Ward on Dec. 3rd, 1907. He was a pale, poorlydeveloped child suffering from tuberculous disease of the right epididymis. Although his parents stated that he had had good health from birth his skeleton showed evidence of rickets and there was also a chronic eczematous condition of the scalp and forehead. The child had never had cod-liver oil and his diet had not been one calculated to lead to the deposit of fat in the tissues. The patient spent two days in hospital awaiting operation, and during this time the temperature and pulse were normal, there was no vomiting, and the urine yielded neither albumin nor sugar. No examination was made for diacetic acid or acetone. The child having been prepared by two drachms of castor oil by the mouth and a soap enema he was anæsthetised with chloroform on Dec. 5th about 11 A.M., the administration lasting for 20 minutes. No ethyl chloride was given and the course of the case was perfectly normal. The right testicle with a portion of adherent scrotal skin was removed as the tuberculous disease was found to have completely destroyed the epididymis and to have encroached also on the body of the gland. The involved structures were adherent to the skin and had broken down into one drachm of thick tuberculous pus. The adherent skin was very thin but had not given way. The wound was closed by silkworm-gut sutures and a small rubber tube was left in the lower angle. The operation was carried out on "aseptic" lines and no antiseptic agent came in contact with the 